\title{
PENGAGENDAAN ISU PANGAN SEBAGAI ISU PANGAN PADA PEMERINTAHAN SUSILO BAMBANG YUDHOYONO (SBY) : STUDI PADA KEBIJAKAN FOOD ESTATE
}

\author{
Ardila Putri \\ Jurusan Ilmu Hubungan Internasional, Fakultas Ilmu Sosial dan Ilmu Politik \\ Universitas Pertamina \\ Email: ardilaputrisip@gmail.com
}

\begin{abstract}
This research examines food securitization as a security issue in Indonesia. Using securitization as the organizing concept and descriptive qualitative methodology with secondary data, the research focuses on food securitization in Soesilo Bambang Yudhoyono era. This research shows that the referent object of food security is food crisis, the securizing actor is government especially president and bureaucrat, also private sector. In addition, the veto actor is advocacy organization, while the veto coalitions are international organization and international advocacy networks. This research concludes that the factors that stimulate the successful of securitization are the issue is an existential threat, political willingness of securitizing actors, also the local and international networking of securitizing actors. While the weaken factors are unstable political condition and veto actors global networking.
\end{abstract}

Keywords: food crisis, securitization, food estate, Indonesia, SBY

\begin{abstract}
ABSTRAK
Penelitian ini menjelaskan tentang proses pengagendaan isu pangan menjadi Isu kemanan di Indonesia. Penelitian ini merupakan penelitian kualitatif dengan model deskriptif-analisis. Proses pengagendaan isu pangan sebagai isu keamanan pada masa pemerintahan SBY dijelaskan dengan menggunakan konsep sekuritisasi. Penelitian ini menunjukkan bahwa referent object dari sekuritisasi isu pangan adalah krisis pangan. Sedangkan secutizing actornya adalah pemerintah, birokrat, dan sektor swasta. Veto actornya adalah gerakan sosial akar rumpur dan veto coalitionnya adalah lembaga-lembaga internasional yang mendukung dan menolak kebijakan pangan skala luas. Penelitian menyimpulkan bahwa kesuksesan pengagendaan isu pangan ini didorong oleh beberapa faktor yaitu keberadaan isu yang memang mengancam, keinginan politik aktor dalam sekuritisasi, bayangan keuntungan masa depan yang akan didapat, juga jejaring lokal dan nasional yang dibangun untuk mendukung proses tersebut. Sedangkan faktor yang memperlemah sekuritisasi adalah kondisi politik yang kerap berubah seiring bergantinya kebijakan juga kekuatan yang dimiliki oleh veto actors dalam membangun jejaring untuk menentang sekuritisasi
\end{abstract}

Kata Kunci: Krisis Pangan, Kebijakan, Sekuritisasi, Food Estate, Indonesia, SBY 


\section{PENDAHULUAN}

Paska dilantiknya Joko Widodo pada tahun 2014 dan 2019, beberapa kebijakan yang pernah dikeluarkan oleh pendahulunya Soesilo Bambang Yudhoyono (SBY) dihapuskan. Salah satunya adalah kebijakan pangan skala besar (Food Estate). Lebih jauh, saat ini Jokowi bahkan tidak menjadikan isu pangan sebagai salah satu isu prioritas dalam kebijakan pemerintahannya. Dalam pidato kemenangannya pada tahun 2019, jokowi fokus pada isu pengembangan sumber daya manusia, sedangkan pada tahun 2014 Jokowi fokus pada pengembangan kemaritiman. Hal yang sama juga terjadi saat era pemerintahan Megawati maupun Gusdur. Pada Era Gusdur, isu demokratisasi dan keberagaman mendapatkan porsi yang lebih besar sebagai isu strategis. Sedangkan pada zaman Megawati isu terorisme dan privatisasi sejumlah perusahaan milik negara menjadi isu yang lebih banyak menjadi perhatian. Hal ini berbeda dengan masa SBY yang menjadikan isu pangan sebagai salah satu isu prioritas utama. Bahkan dalam kebijakan MP3I, pangan adalah salah satu isu strategis yang menjadi fokus utama pemerintah dengan mencanangkan kebijakan Food Estate yang dilakukan di beberapa daerah terutama Kalimantan dan Papua. Oleh karena itu, menarik untuk dikaji bagaimana isu pangan bisa menjadi isu prioritas di zaman SBY walaupun dizaman pendahulu dan penggantinya kebijakan ini dikalahkan oleh isu-isu lain yang dianggap lebih strategis.

Penelitian ini bertujuan untuk menjelaskan proses pengagendaan isu pangan sebagai isu keamanan dalam pemerintahan SBY. Lebih jauh, dengan menjelaskan pengagendaan isu pangan sebagai sebuah isu keamanan pada masa SBY, penelitian ini kemudian dapat menjadi acuan untuk menjelaskan alasan mengapa kemudian isu ini tidak menjadi prioritas di era selanjutnya. Penelitian ini juga akan memberikan pemahaman tentang faktor-faktor penyebab keberhasilan dan kegagalan dari proses sekuritisasi sehingga akan memberikan pemahaman kepada pengkaji isu keamanan non-tradisional tentang kajian-kajian terkait.

\section{METODE PENELITIAN}

Penelitian ini merupakan penelitian kualitatif dengan model deskriptif-analitis. Dalam tulisan ini, penulis akan terlebih dahulu menjelaskan data dan fakta terkait sekuritisasi isu pangan, kemudian menganalisa faktor penyebab keberhasilan dan kegagalan sekuritisasi. Data 
dikumpulkan melalui review literatur dari artikel jurnal, buku, laporan para pemangku kepentingan terkait, juga melalui penelusuran internet dengan kata kunci "krisis pangan; food estate; ketahanan pangan; food security; mifee; pangan skala luas".

Konsep yang digunakan dalam penelitian ini adalah sekuritisasi yang diungkapkan oleh Copenhagen School. Secara sederhana sekuritisasi dapat diartikan sebagai proses pengagendaan sebuah isu menjadi isu keamanan. Dalam hal ini, isu publik yang awalnya bersifat nonpolitik (isu yang tidak dipolitisasi, isu publik ini tidak menimbulkan debat publik ataupun kebijakan dari pemerintah, dengan kata lain negara tidak berurusan dengan isu ini) kemudian berubah menjadi isu politik (menjadi bagian dari kebijakan publik, membutuhkan keputusan pemerintah dan alokasi sumber daya dan dianggap sebagai bentuk tata kepemerintahan bersama) kemudian menjadi isu keamanan jika isu itu dianggap sebagai ancaman yang benar adanya, mempunyai ukuran darurat dan membenarkan tindakan diluar prosedur politik resmi (Buzan, 23-24).

Untuk membimbing penelitian agar lebih terarah, maka penelitian ini mengadopsi kerangka berpikir yang ditawarkan oleh Scott D. Watson untuk memahami sekuritisasi. Watson menyatakan bahwa perlu melakukan identifikasi terhadap beberapa hal untuk menjelaskan sekuritisasi yaitu mengidentifikasi bidang isu, mengidentifikasi episode-episode sekuritisasi, mengidentifikasi kondisi-kondisi yang menyebabkan sekuritisasi itu berhasil atau gagal (Watson, 2009). Dari kerangka berpikir yang diungkapkan Watson tersebut maka peneliti merumuskan kerangka berpikir penelitian sebagai berikut:

a. Mengidentifikasi bidang isu akan berfokus pada masalah pangan di Indonesia pada era pemerintahan SBY, mengidentifikasi hubungan antar unit aktor dalam proses pengagendaan isu dan akibat-akibatnya kepada keluarannya dalam bentuk kebijakan dan aksi.

b. Episode-episode sekuritisasi mencakup penjelasan dan pemaparan mengenai tindakan pengagendaan isu pangan yang dimunculkan dan ditangkap oleh publik. Hal ini dapat dilihat dari kemunculan isu ini di forum publik dalam bentuk penyebaran di media masa baik media cetak maupun elektronik serta pidato-pidato resmi pemerintah, juga melihat perubahan kebijakan yang terjadi dalam waktu tertentu, dalam penelitian ini akan dilihat semenjak tahun 2004 hingga 2014 yaitu semasa pemerintahan SBY.

c. Kondisi-kondisi yang menyebabkan sekuritisasi itu berhasil atau gagal dihubungkan dengan prinsip dan pendekatan yang digunakan oleh pemerintah nasional, posisi shareholders dan isuisu pangan dan keamanan pangan yang dipermasalahkan di Indonesia . 


\section{PEMBAHASAN}

\section{Krisis Pangan Sebagai Referent Object}

Berdasarkan Universal Declaration of Human Right (1948) dan The International Convenant on Economic, Social and Cultural Right (1966) pangan dianggap sebagai Hak Asasi Manusia. Kebutuhan akan pangan merupakan kebutuhan primer setiap manusia yang tidak bisa tergantikan, hal ini menyebabkan pangan mempengaruhi kehidupan manusia dari berbagai sektor baik itu sektor ekonomi, sosial, politik ataupun budaya (Khudori, 2008). Dikarenakan begitu pentingnya peran pangan, maka PBB memiliki lembaga khusus untuk menangani isu pangan yaitu FAO. FAO berhasil membuat negara anggota PBB memprioritaskan kebijakan pangan. Salah satu keberhasilan FAO tersebut yaitu dengan diselenggarakannya World Food Summit pada tahun 1996 di Roma (Italia), yang dihadiri oleh 186 negara peserta (termasuk European Community). Pertemuan ini menghasilkan Rome Declaration World Food Security and World Food Summit 1996. Sebanyak 112 kepala negara dan pemerintahan serta 70 pejabat tinggi menandatangani deklarasi ini, konsekuensi yang ditimbulkan saat deklarasi ini ditandatangani yaitu setiap negara penandatangan harus menindaklanjuti hasil deklarasi di negara masing-masing.

Di Indonesia sendiri, tindakan pengagendaan isu pangan sebagai isu keamanan bukanlah hal baru. Semenjak Indonesia merdeka hingga sekarang, pangan masih dianggap sebagai isu strategis. Walaupun begitu, proses pengagendaan isu pangan menjadi isu keamanan berbedabeda disetiap masa kepemerintahan presiden Indonesia, hal ini dikarenakan Indonesia menganut sistem presidensial. Di era pemerintahan SBY sekuritisasi pangan melahirkan sebuah kebijakan yang bernama Food Estate (FE) atau kebijakan pangan skala luas. FE merupakan salah satu kebijakan strategis SBY dalam program kerja 100 hari kabinet Indonesia Bersatu. Selain itu, perintisan kebijakan ini telah dikeluarkan melalui beberapa kebijakan pemerintahan SBY sebelumnya yaitu Revitalisasi Pertanian, Perikanan, dan Kehutanan, serta kebijakan umum dewan ketahan pangan 2005-2009 dan 2010-2014.

Adapun referent object (sesuatu yang dianggap sebagai sebuah ancaman) dari sekuritisasi isu pangan yang dilakukan oleh pemerintah Indonesia adalah krisis pangan itu sendiri. Ketakutan atas efek krisis pangan dunia yang akan melanda Indonesia menjadi alasan 
utama isu pangan disekuritisasi oleh pemerintah Republik Indonesia. Laporan lembaga internasional (FAO) mengenai ancaman krisis pangan yang akan melanda dunia serta adanya upaya untuk mengamankan pangan menjadi dasar utama atas asumsi ini.

Pemerintah dengan speech act yang dilakukan telah menyatakan bahwa krisis pangan merupakan sesuatu yang mengancam dan perlu adanya tindakan-tindakan darurat untuk menanggulangi isu tersebut. Speech act ini terlihat dalam pidato resmi Presiden RI (Soesilo Bambang Yudhoyono) dalam beberapa kesempatan seperti saat panen raya, konferensi dewan ketahanan pangan serta pada acara penyerahan penghargaan ketahanan pangan. Selain itu dalam sebuah buku "Harus Bisa! Seni Memimpin Ala SBY" terlihat jelas bagaimana SBY membangun isu pangan sebagai isu keamanan dengan melakukan tindakan secara domestik dan internasional. Media cetak juga sering mengeluarkan pemberitaan tentang isu pangan, dengan mengutip pernyataan dari pemerintah, swasta, civil society ataupun pihak terkait lainnya. Selain itu pemerintah Indonesia melakukan institusionalisasi terhadap isu pangan terutama untuk menanggulangi krisis pangan dengan mendirikan Dewan Ketahanan Pangan, pemerintah juga telah melakukan bebagai perubahan kebijakan dan aplikasi kebijakan untuk menanggulangi krisis pangan yang dianggap mengancam tersebut. Institusionalisasi sebuah isu merupakan bentuk tindakan darurat yang nyata, yang menegaskan bagaimana sebuah isu itu penting dan ada aspek ancaman yang nyata adanya di dalam isu tersebut yang perlu ditangani (Buzan, 2728).

Kebijakan FE merupakan salah satu tindakan darurat yang dilakukan pemerintah untuk menanggulangi krisis pangan (Dewan Ketahanan Pangan, 2009). Kebijakan FE sebagai bentuk dari tindakan darurat dalam implementasinya dilakukan dalam sebuah bentuk prosedur khusus, dimana dalam implementasinya bisa saja tidak mematuhi dan melanggar aturan-aturan yang sudah ada. Contohnya adanya izin melakukan penebangan hutan dan membuka lahan gambut padahal disaat yang bersamaan Indonesia dalam forum-forum internasional yang membahas perubahan iklim telah berkomitmen untuk menurunkan emisi gas rumah kaca dan menjaga hutan yang dianggap sebagai paru-paru dunia (Greenomics Indonesia, 2011). Selain itu, dalam pembebasan lahan, pemerintah ikut serta secara proaktif untuk mengambil tanah milik masyarakat dan diserahkan kepada perusahaan walaupun disaat yang bersamaan terjadi penentangan dari masyarakat setempat dan adanya advokasi dari NGO baik nasional maupun internasional 


\section{Aktor-aktor dalam kebijakan Sekuritisasi}

Securitizing actor merupakan aktor yang melakukan sekuritisasi. securitizing actor bisa dikelompokkan menjadi 3 kelompok yaitu lead actor (aktor utama yang melakukan sekuritisasi), veto actor (aktor yang memperlemah sekuritisasi), dan veto coalition (kelompok negara yang bisa memperkuat atau memperlemah sebuah isu). Dalam sekuritisasi isu pangan di Indonesia yang dianggap sebagai lead actor adalah birokrat dan swasta. Hal ini disasarkan pada asumsi bahwa pemerintah dan swasta adalah pihak yang paling gencar mengemukakan tentang pentingnya isu pangan dan perlunya pembangunan pangan skala luas untuk menanggulangi krisis pangan.

Presiden sebagai kepala negara dan kepala pemerintahan telah mengeluarkan kebijakan terkait FE, melakukan institusionalisasi isu melalui dewan ketahanan pangan, serta membangun kerjasama dengan berbagai negara dan organisasi internasional terkait untuk ikut serta dalam menyuarakan isu keamanan pangan. Lebih jauh, pemerintah secara proaktif ikut serta dalam proses pembebasan lahan dengan mengeluakan kebijakan konsensi walaupun masih banyak terjadi penentangan dari masyarakat adat maupun NGO serta menjadi ironi disaat pemerintah juga sedang gencarnya untuk ikut serta dalam penanggulangan perubahan iklim dengan melakukan konservasi terhadap hutan. Selain presiden dan beberpa kementerian, gubernur dan bupati juga jajarannya juga merupakan aktor yang juga turut aktif sebagai lead actors, hal ini terlihat dari keaktifan para gubernur dan bupati dalam berkoordinasi dengan pemerintah pusat dan swasta juga menyediakan sarana dan prasanara terkait untuk kelancaran program ini.

Selain itu, swasta sebagai aktor yang diuntungkan dari kebijakan FE, turut serta dalam melakukan berbagai kajian dan diskusi bersama pemerintah terhadap peluang FE. Pernyataanpernyataan pihak swasta di media masa maupun website pribadinya terkait ancaman isu pangan dan menganggap FE sebagai jawaban dari permasalahan ini adalah salah satu bukti perusahaanperusahaan ini adalah aktor yang ikut melakukan sekuritsasi. Lebih jauh, jika dikaji dari kepentingan ekonomi dan bisnis, aktor ini adalah aktor yang paling diuntungkan dari proses sekuritisasi. Dikarenakan terjadinya sekuritisasi, maka aktor swasta memiliki kemudahan untuk mendapatkan modal dan lahan untuk digarap. Pihak swasta dapat dengan mudah melakukan perizinan dan pengembangan, juga mendapatkan keuntungan dari kajian-kajian yang dilakukan oleh pemerintah maupun lembaga terkait. Pihak swasta yang terlibat dalam FE ini antaranya adalah Medco Group (PT Selaras Inti Semesta, PT Medco Papua Alam Lestari, PT Medco Papua 
Industri Lestari, PT Kasuari Komoditas, PT Energi Mitra Merauke, PT Tebu Wahana Kreasi, PT Papua Daya Bioenergi), Rajawali Group (PT Cenderawasih Jaya Mandiri, PT Karya Bumi Papua), Korindo Group (PT Berkat Citra Abadi, PT Dongin Prabhawa, PT Inocin Abadi, PT Balik Papan Forest Indo, PT Indosawit Lestari), Daewoo International Corporation (PT Bio Inti Agrindo, PT Muting Jaya Lestari, PT Digul Agro Lestari, PT Papua Agro Lestari, PT Ulilin Agro Lestari), Central Cipta Murdaya Group (PT Hardaya Sawit Papua, PT Hardaya Sugar Papua), Wilmar International (PT Anugrah Rejeki Nusantara, PT Agriprima Cipta Persada), Plasma Nutfah Marind Papua, China Gate Agriculture Development, Bagun Cipta Sarana (PT Cipta Papua Agri Lestari), Agro Mandiri Semesta Plantations (PT Agrinusa Persada Mulia), Sumber Alam Sutra, Perusahaan milik pemerintah (PT Padi Energi Nusantara, PT Sang Hyang Seri, PTPN IX, PTPN XI, PT Rajawali Nusantara Indonesia), Modern Group (PT Agri Surya Agung, PT Mega Surya Agung, PT Kharisma Agri Pratama, PT Nusanatara Agri Resources, PT Wanamulia Sukses Sejati) (Forest People Program, 2013).

Veto actor dalam sekuritisasi pangan pada era SBY adalah Civil society seperti SPI, PUSAKA, SORPATOM, AMAN, Greenomics Indonesia, Sawit Watch, AGRA dan PAN-AP. Gerakan sosial akar rumput ini merupakan veto actor karena melalui lobi yang mereka lakukan mereka berusaha untuk memperlemah kebijakan FE. Lobi-lobi yang dilakukan oleh lemabga pemerintah ini tidak hanya di sektor domestik melainkan juga melalui jejaring advokasi internasional yang mereka miliki. Sedangkan Veto coalition dalam kebijakan FE terbagi dua yaitu aktor yang memperkuat sekuritisasi yaitu beberapa lembagai internasional terkait seperti Food and Agricultural Organization (FAO) dan World Trade Organization (WTO), World Bank (Bank Dunia), dan International onetary Funda (IMF). Lembaga-lembaga ini merupakan kelompok negara yang membentuk perjanjian mengenai isu-isu penting dunia termasuk pertanian, serta memainkan peran sentral dalam arah kebijakan perekonomian dunia. Sedangkan aktor veto coalition yang melemahkan program ini adalah jejaring petani internasional La Via Campesina dan jejaring masyarakat adat internasional Forest Peoples Program.

\section{EPISODE SEKURITISASI}

Pemerintah SBY tidak langsung merumuskan kebijakan FE di awal pemerintahannya, melainkan mengeluarkan kebijakan-kebijakan yang mendukung sebelumnya hingga kemudian mengeluarkan kebijakan FE secara langsung. Kebijakan FE disebutkan secara langsung pada 
tahun 2008 dan dipertegas kembali pada 2009 tapi jauh sebelum itu kebijakan ini telah disiapkan dengan berbagai kebijakan ataupun pernyataan pemerintah.

Pemerintah Indonesia mengeluarkan kebijakan FE melalui rangkaian panjang proses pengagendaan kebijakan. Proses awal dari pengagendaan ini melalui kebijakan Revitalisasi Pertanian, Perikanan dan Kehutanan pada tahun 2005. Kemudian disusul dengan Kebijakan Umum Dewan Ketahanan Pangan 2005-2009. Kemudian disusul dengan Instruksi Presiden No. 5/2008 tentang Fokus Program Ekonomi 2008-2009, kemudian dilanjutkan oleh PP No 18 Tahun 2010, tentang FE atau pertanian tanaman pangan berskala luas. Dan ditegaskan kembali dalam Kebijakan Umum Dewan Ketahanan Pangan 2010-2014. Untuk mendorong terealisasinya FE ini maka dibuatlah kebijakan-kebijakan pelengkap lain seperti UU No.39 Th 2009 tentang Kawasan Ekonomi Khusus (KEK), UU No. 41 Th 2009 tentang perlindungan lahan pertanian pangan berkelanjutan, UU No. 32 Th 2009 tentang perlindungan dan pengelolaan lingkungan hidup, UU. No. 25 Th 2007 tentang penanaman modal, UU No. 26 Th 2007 tentang penataan ruang, PP No. 26 Th 2008 tentang RTRWN, PEPRES 77 Th 2008 jo No. Perpres N0. 111 Th 2008 tentang bidang usaha terbuka dan tertutup, PP 18 Th 2010 tentang usaha budidaya tanaman, PP. 10 Th. 2010 tentang tata cara perubahan peruntukan dan fungsi kawasan hutan, PP 11 Th. 2010 tentang penerbitan dan pendayagunaan tanah terlantar (Buku Pintar FE, 2013).

Rencana FE pertama kali diungkapkan ke Publik pada tahun 2006 yaitu padaa saat panen Raya musim tanam 2005/2006 di Merauke yang dihadiri oleh presiden Susilo Bambang Yudhoyono. Kemudian, setelah panen raya, Desember 2007, Bupati Merauke diundang oleh kementerian perekonomian untuk menyampaikan konsep Merauke Integrated Rice Estate (MIRE) yang digagasnya. Tiga bulan kemudian, tahun 2008 barulah isu ini dikeluarkan dalam instruksi presiden (Ito, 2013).

Selain tindakan yang dilakukan secara domestik, presiden SBY juga melakukan tindakan secara internasional dalam sekurtisasi isu pangan, pada tanggal 27 Maret 2008, presiden SBY menulis surat kepada sekjen PBB Ban Ki Moon. Dalam surat itu presiden mendorong sekjen PBB untuk menyelenggaraakan konferensi pada tahun itu juga untuk mencari solusi global terhadap krisis energi dan pangan. Seminggu kemudian, SBY menyurati Presiden Bank Dunia Robert Zoellik, dan menyatakan dukungannya terhadap gagasan "new deal for global food policy" yang baru dilontarkan Zoellick. Presiden SBY juga menghimbau Zoellick untuk tidak 
membuang waktu dalam mengambil inisitif-inisiatif untuk mewujudkan visinya kea rah kondisi pangan global yang lebih baik. Kemudian, Presiden juga menyurati Perdana Menteri Jepang, Yasuo Fukuda selaku ketua KTT G-8 yang akan diadakan di Hokkaido awal Juli 2008. Dalam suratnya presiden SBY mengusulkan agar KTT G-8 plus 8, yakni pertemuan khusus negaranegara G-8 dengan 8 negara yang berperan penting dalam perubahan iklim (termasuk Indonesia) juga membahas krisis pangan karena keterkaitan isu ini dengan perubahan iklim. Setelah itu, awal Mei 2008 Presiden SBY menulis surat kepada Perdana Menteri Singapura Lee Hsien Long sebagai ketua ASEAN Standing Committee dan juga kepada seluruh pemimpin ASEAN, perihal krisis energi dan pangan. Dalam surat kepada para pemimpin ASEAN, SBY mengusulkan agar segera diadakan pertemuan khusus para pemimpin ASEAN untuk membahas respon bersama ASEAN untuk mengatasi krisis energy dan pangan (Djalal, 2008).

Selanjutnya, pada tanggal 17 april 2008 diadakan rapat kabinet, KADIN (Kamar Dagang Indonesia) juga dilibatkan dalam rapat ini. Rapat ini dipimpin langsung oleh presiden SBY di Yogyakarta. Pertemuan ini bertujuan untuk merumuskan respon darurat terhadap naiknya harga pangan dan energi dunia. Presiden menawarkan solusi untuk menanggulangi krisis yaitu "meningkatkan produksi dan produktivitas pangan, energi dan mineral guna meningkatkan perekonomian indonesia: dari krisis menjadi peluang”. Di akhir pertemuan presiden meminta KADIN untuk menyiapkan solusi strategis mengenai ide ini (Djalal, 2008).

Setelah itu, pada pertemuan kedua tanggal 30 April 2008 presiden SBY menegaskan tujuh poin utama yang sangat penting, yang sangat berhubungan dengan kebijakan food and energy estate yaitu perlu ditumbuhkan large scale farmers, perlunya go beyond self sufficiency on food and energy, masih ada 1,7 juta HGU yang telah diberikan izin tapi belum digarap, mengajak pihak swasta berpartisipasi dalam program public private partnership, terutama dalam hal infrastruktur. Khusus untuk pangan perlu dipikirkan untuk mendirikan special agricultural zone (untuk agrobisnis dan agroindustri, mungkin berjumlah lima buah) diberbagai daerah di Indonesia (untuk menjadi sentra-sentra produksi pangan). Jadi bukan hanya special economic zone saja seperti di Batam, Bintan dan Karimun. Serta perlu memperbaiki supply chain management atau distribusi dan perlu koordinasi lintas sectoral (Djalal, 2008).

Mengenai usulan KADIN untuk membentuk komite kebijakan peningkatan produktivitas pangan, energi dan mineral (K2P3EM) langsung disetujui presiden, presiden langsung menjadi ketua komite tersebut. Nama komite tersebut diubah dari komite kebijakan 
menjadi komite aksi. Tim KADIN kemudian diperintahkan untuk menyusun plan of action yang kongkrit dalam waktu sepuluh hari, dengan tenggat waktu yang jelas untuk setiap usulan kegiatan, termasuk yang bertanggung jawab atas kegiatan tersebut (Djalal, 2008).

Kemudian, pada 28-29 Januari 2010 KADIN melaksanakan seminar dan pameran dengan tema "feed the nation and feed the world". Dalam konferensi ini KADIN mempresentasikan roadmap pangan mereka yang berjudul "feed the world", yang mencakup 16 makanan untuk memenuhi permintaan domestik dan internasional. Pemerintah diharapkan mampu meyediakan lahan pertanian, kebijakan penggunaan lahan yang konsisten disetiap tingkat, proses yang mudah untuk merealisasikan lahan dan keamanan penggunaan dan jaminan hak atas tanah (Jakarta Globe, 2013).

May 2010 BKPRN (Badan Koordinasi Penataan Ruang Nasional) mengeluarkan rekomendasi setelah Instruksi Presiden untuk membuat sebuah perencanaan tata ruang Merauke, Instruksi ini diterima BKPRN pada September 2009. Rekomendasi tersebut terdiri dari 6 poin utama yaitu:

1. Untuk menggambarkan wilayah merauke, yang terdiri dari 18 kecamatan dalam kabupaten Merauke, Mappi dan Boven Digul

2. Untuk menyediakan lahan bagi pertanian tanaman pangan

3. Untuk mendirikan gugusan pusat produksi yang terdiri dari 10 gugusan

4. Untuk memprioritaskan penggunaan lahan pada area bukan hutan dan area hutan yang diperuntukkan sebagai hutan produksi.

5. Untuk mengembangkan strategi kerjasama dan menempatkan prioritas utama bagi pengembangan infrastruktur

6. Untuk memperhatikan hak atas tanah dan isu lembaga komunitas lokal serta isu lainnya. Seperti perkembangan energy alternative, kemudahan izin sebagai dorongan investasi, siaga bencana alam, konsep agropolitan, dan lain-lain.

Untuk memastikan rekomendasi ini diterima, maka diadakan pertemuan pada 6 juni 2010 di Jayapura. Topik utama yang menjadi perdebatan adalah berapa banyak lahan yang akan digunakan. Pemerintah propinsi Papua bersikeras hanya memberikan izin 500.000 ha dari 1,2 juta ha yang diusulkan pemerintah Merauke yang didukung oleh Kementerian Pertanian dan Kementerian Tenaga Kerja. Pemerintah propinsi memutuskan hal tersebut dikarenakan adanya komitmen presiden untuk menurunkan emisi 26\% sesuai dengan UNFCCC Copenhagen, hal ini 
didukung oleh kementerian kehutanan. Disisi lain pemerintah Kabupaten Merauke menggunakan kebijakan feed the nation and feed the world sebagai alasan pengajuan 1,2 juta ha lahan tersebut. pertemuan tersebut gagal menemui kesepakatan. Kemudian diadakan lagi pertemuan di Jakarta yang memutuskan lahan yang bisa digunakan adalah 550.000 ha sesuai dengan yang dianjurkan pemerintah papua sampai adanya persetujuan konfersi hutan dari kementerian kehutanan (Boven Digoel Post, 2010). Perbedaan pandangan antar departmen ini menujukkan bahwa aplikasi kebijakan FE masih menimbulkan polemik bahkan dikalangan birokrat pemerintah RI.

Setelah itu, pada Juni 2010 menteri pertanian melaporkan grand design MIFEE kepada Presiden, walaupun kejelasan luas lahan masih belum menemui titik temu. Kemudian pada 11 Agustus 2010 MIFEE secara resmi diluncurkan. Peluncuran MIFEE pada Agustus 2010, tidak diketahui warga setempat (Kompas, 2010). Kemudian megaproyek MIFEE ditolak oleh berbagai civil society hingga kini.

\section{KONDISI SEKURITISASI}

Kondisi yang mempermudah dalam proses pengagendaan dan penerapan kebijakan FE di Indonesia adalah karena posisi sosial dan politik yang dimiliki oleh pemerintah SBY sebagai aktor utama sekuritisasi. Pemerintah memiliki wewenang untuk menetapkan kebijakan tanpa harus konsultasi langsung dengan berbagai pihak. Instruksi presiden serta peraturan pemerintah tidak memerlukan persetujuan dari DPR sehingga implementasi Inpres dan PP bisa dilakukan dengan sangat cepat.

Selain itu dengan menjadikan isu pangan sebagai sesuatu yang mengancam dan membutuhkan tindakan darurat menjadikan kebijakan ini bisa diimpelementasikan dengan cepat. Ancaman krisis pangan merupakan hal yang bersifat intersubjektif, hal ini didasarkan pada krisis pangan yang secara objektif memang mengancam, hal ini dikarenakan pangan merupakan kebutuhan primer yang tak tergantikan dan semua pihak menyatakan isu ini sangat penting. Kemudian pangan juga dianggap sebagai ancaman bersifat subjektif dimana adanya konstruksi sosial yang dilakukan aktor untuk melabeli isu pangan sebagai isu kemanan.

Dilihat dari tujuannya, FE sebagai cara untuk mencapai swasembada pangan membuat kebijakan ini semakin didukung. Hal ini dikarenakan Indonesia saat ini memang belum mencapai swasembada pangan (kembali). Indonesia mencapai swasembada beras pada tahun 1984 Kemudian pada tahun 2008 tapi swasembada ini tidak berlangsung lama sehingga 
ketergantungan terhadap beras serta pangan impor lainnya masih sangat tinggi. Secara logis semua bangsa di dunia tentu saja menginginkan swasembada pangan dan meminimalisir impor pangan serta meningkatkan ekspor pangan. Sehingga implementasi kebijakan FE menjadi layak untuk dilakukan.

Sistem pangan berkelanjutan dianggap sebagai pilar utama pembangunan era abad ke-21 karena adanya kekhwatiran dampak buruk dari pertanian yang tidak terorganisir dengan baik. investasi di bidang pertanian merupakan cara yang efektif untuk mempromosikan produktivitas pertanian, mengurangi kemiskinan dan meningkatkan pemeliharaan lingkungan. Selain itu dengan penentuan wilayah khusus penanaman pangan akan mengurangi dampak buruk degradasi lahan. Alih fungsi lahan pertanian dan lahan terlantar menjadi isu strategis yang perlu dibenahi menuju terwujudnya ketahanan pangan di Indonesia. Dengan adanya kawasan pertanian khusus dan berkelanjutan maka alih fungsi lahan akan bisa ditekan.

FE juga akan meminimalisir devisa Negara yang akan dihabiskan untuk mengimpor pangan karena FE akan menyumbangkan produksi pangan dalam jumlah besar terhadap bangsa Indonesia. Selain itu jika megaproyek ini menghsilkan pangan yang melebihi kebutuhan pangan Indonesia maka kegiatan ekspor pangan bisa dilakukan sehingga devisa negara akan bertambah.

Selain itu krisis pangan dunia, fluktuasi harga pangan serta menipisnya cadangan pangan dunia juga memicu tingginya keinginan aktor untuk mengambil kebijakan ini. Jika dilihat dari berbagai laporan FAO maka menimbulkan keresahan tentang bagaimana keadaan pangan dunia dimasa datang. Tentu saja ini menakutan bagi seluruh negara di dunia dan dilain pihak ini juga menjadi peluang besar bagi berbagai negara yang memiliki sumber daya untuk mengembangkan pertanian mereka sehingga akan memberikan keuntungan dimasa depan (Djalala, 2008).

Sedangkan faktor penghambat dari kebijakan ini yaitu pihak-pihak yang merasakan dampak dari kebijakan ini tidak memiliki pemahaman yang sama mengenai kebijakan yang bersangkutan. Pemerintah Indonesia menginginkan kebijakan ini terimplementasi dikarenakan keinginan untuk tercapainya swasembada pangan serta untuk mengantisipasi akibat buruk dari krisis pangan tapi yang merasakan efek dari kebijakan ini secara langsung yaitu masyarakat. Dalam kerangka MIFEE yang merasakan akibatnya yaitu masyarakat suku adat yang memiliki standar kehidupan bersanding dengan alam, masyarakat adat tidak memiliki keinginan untuk mengeksploitasi alam melainkan memiliki keinginan untuk melestarikannya. Hal ini juga dipicu kebijakan yang bersangkutan tidak dibutuhkan masyarakat setempat, masyarakat setempat 
mendapatkan sumber pangan dari alam sekitar, sehingga hal ini memicu konflik kepentingan antara pemerintah dengan masyarakat lokal memiliki dan berada di kawasan yang akan digarap (PUSAKA, 2011).

Selain itu, sentiment negatif terhadap kebijakan pemerintah memang cukup tinggi. Apalagi di Papua, ketakutan akan dieksploitasinya sumber daya yang dimiliki menyebabkan masyarakat menolak mendukung kebijakan ini. Selama ini alam Papua telah dieksploitasi dengan pendekatan Up-Bottom (atas-bawah), pengkonsepan kebijakan hanya dilakukan oleh pemerintah dan sektor swasta, tanpa partisipasi masyarakat sipil atau pemangku kepentingan lainnya (PUSAKA, 2011).

Disamping itu, munculnya gerakan aktor non-negara juga menjadi faktor yang menghambat dan melemahkan, banyak gerakan aktor non-negara yang menolak kebijakan FE ini. Aktor tersebut memiliki akses yang leluasa untuk menggalang dukungan dilevel domestik terbawah yaitu masyarakat adat sampai dilingkungan internasional tertinggi seperti PBB.

Adanya semangat perlawanan terhadap sistem kapitalisme global merupakan hal yang menyebabkan berbagai kebijakan banyak ditentang oleh aktor non-negara dan masyarakat. Pada era 2000an semangat perlawanan ini semakin tinggi karena semakin lebarnya jurang pemisah antara negara maju dan negara berkembang serta efek buruk dari eksploitasi yang dilakukan secara besar-besaran oleh kaum kapitalisme. Dalam urusan pangan sendiri, saat ini perusahaanperusahaan telah menguasai rantai produksi makanan mulai dari benih, produksi, distribusi sampai ke pemasaran sehingga menimbulkan stigma negatif mengenai kapitalisasi pertanian terebut. Lebih jauh, kebijakan yang dibuat mengorbankan beberapa aspek penting lingkungan. Papua dan Kalimantan memiliki hutan yang cukup luas dan lebat, jika kebijakan FE ini diimplementasikan maka hutan dan lahan gambut akan dikorbankan. Pembukaan lahan baru akan menyebabkan perubahan ekosistem dan keseimbangan ekologi, hilangnya biodiversitas, hilangnya daerah tangkapan air serta menimbulkan banjir dan kekeringan, menimbulkan instrusui air laut, dan mempercepat ancaman pemanasan global.

Kebijakan yang bersangkutan juga mengorbankan masyarakat adat yang saat ini memang semakin terpinggirkan di dunia. Masyarakat adat/Masyarakat pribumi akan kehilangan sumber bahan pangan mereka yang disebabkan oleh berkurangnya wilayah hutan, nilai-nilai kearifan lokal masyarakat akan tergerus dengan adanya kegiatan industrialisasi dan akan berkembang sistem feodal baru dimana petani kecil dan masyarakat sekitar hanya sebagai buruh bagi 
pemodal. Lebih jauh, industrialisasi pertanian secara besar-besaran yang dilakukan oleh pihak swasta sangat berbeda sekali dengan kebudayaan yang selama ini dimiliki oleh masyarakat Indonesia. Pemenuhan kebutuhan pangan tidak hanya menyangkut masalah bagaimana pangan tersebut ada dalam jumlah banyak melainkan juga menyangkut budaya turun temurun yang ada di Indonesia. Kebudayaan agraris yang diwariskan dari nenek moyang masih mengakar kuat ditengah masyarakat. Jika kebijakan FE diimplementasikan maka akan terjadi pergeseran kebudayaan, contohnya saja tradisi panen raya dan semangat gotong royong masyaarakat akan semakin tergerus. Kebijakan FE juga akan menyebabkan karakter pertanian dan pangan Indonesia akan bergeser dari peasant-based and family-based agriculture (pertanian yang bertopang pada petani dan keluarga) menjadi corporate-based food and agriculture production (produksi pertanian berdasarkan pada perusahaan).

\section{KESIMPULAN}

Jika dilihat dari gerakan pengagendaan (securizing move) dan dikeluarkannya kebijakan FE maka dapat disimpulkan bahwa terjadi proses pengagendaan isu pangan menjadi isu keamanan pada era kepemerintahan SBY. Pangan dianggap sebagai isu yang sangat penting. Krisis pangan dianggap sebagai referent object (sesuatu yang mengancam) sehingga diambil lagkah-langkah untuk mengatasinya. Dalam hal ini langkah yang diambil yaitunya kebijakan food estate (pembangunan usaha pangan dalam skala luas). Sebelum kebijakan ini dikeluarkan maka terjadi proses panjang pengagendaan. Dimana adanya tindakan-tindakan yang dilakukan oleh securitizing actor untuk melabeli isu sebagai isu keamanan dan menawarkan solusi untuk mengatasi hal tersebut baik itu tindakan-tindakan yang dilakukan secara domestik maupun tindakan-tindakan yang dilakukan secara internasional. Kesuksesan pengagendaan isu pangan ini didorong oleh beberapa faktor yaitu keberadaan isu yang memang mengancam, keinginan politik aktor dalam sekuritisasi, bayangan keuntungan masa depan yang akan didapat sehingga swasta sanagat memainkan peran dalam pengagendaan, juga jejaring lokal dan nasional yang dibangun untuk mendukung proses tersebut. Sedangkan faktor yang memperlemah sekuritisasi adalah kondisi politik yang kerap berubah seiring bergantinya kebijakan juga kekuatan yang dimiliki oleh veto actors dalam membangun jejaring untuk menentang sekuritisasi. 


\section{DAFTAR PUSTAKA}

Buzan, Barry, Ole Waever and Jaap De Wilde. Security a New Frame Work For Analysis. United Kingdom: Lynne Rienner Publisher, 1998.

Buzan, Barry. People, States and Fear. United Kingdom: Lynne Rienner Publisher, 1991.

Buzan, Barry and Lene Hansen. International security III, Widening Security.(ed) USA: Sage Publication, 2007

Buzan, Barry and Lene Hansen. The Evolution of International Security Studies. (UK: Cambridge University Press, 2009)

Departemen Pertanian. Rencana Pembangunan Pertanian Tahun 2005-2009. Jakarta: Departemen Pertanian, 2006.

Dewan Ketahanan Pangan.Kebijakan Umum Ketahanan Pangan 2010-2014. Jakarta: Dewan Ketahanan Pangan, 2009.

Djalal, Dino Patti. Harus Bisa! Seni Memimpin Ala SBY. Jakarta: R n W, 2008.

FAO. Agricultural Investment Funds For Developing Countries. Italia: FAO, 2010

FAO. The State Of Food And Agriculture. Italia: FAO

FAO. Land Grab Or Development Opportunity, Agricultural Investment And International Land Deals In Africa. (Italia: FAO)

Floyd, Rita. Security And The Environment: Securitisation Theory and the U.S Environment Security Policy. London: Cambridge University Press, 2010 .

Khudori. Ironi Negeri Beras. Yogyakarta: INSIST Press, 2008

Serikat Petani Indonesia. Catatan Pembangunan Pertanian, Pedesaan dan Pembaruan Agraria 2011

Tim Pengembangan FE. Buku Pintar FE. Jakarta: Departemen Pertanian, 2010

Watson, Scott D. The Securitization Humanitarian Migration, Digging Moats and Sinking Moats. United Kingdom: Routledge, 2009.

Zakaria, R. Yando, Emilianus Ola Kleden, Y.L Franky. MIFEE Tak Terjangkau Angan Malind. Jakarta: Yayasan PUSAKA, 2011.

Syaukat, Yusman. Kebijakan Pengembangan Food Estate di Merauke.

Takeshi Ito, Noer Fauzi Rachman, Laksmi A. Savitri. Naturalizing Land Dispossession: A Policy Discourse Analysis of the Merauke Integrated Food and Energy Estate.

http://bulletin.penataanruang.net/index.asp?mod=_fullart\&idart $=343$ http://www.downtoearth-indonesia.org/id/story/rencana-besar-untuk-papua http://www.fao.org/wfs/index_en.htm

http://www.thebrokeronline.eu/Blogs/A-new-agriculture-for-food-security/The-emergingsecuritisation-of-food http://www.thejakartaglobe.com/archive/can-indonesia-feed-the-world/ http://www.thejakartapost.com/news/2010/01/30/indonesia-pledges-feed-world039.html http://www.un.org/en/documents/udhr/index.shtml http://www2.ohchr.org/english/law/cescr.htm 
www1.pu.go.id/uploads/berita/ppw1504109t.htm

http://www.presidenri.go.id/index.php/pidato/2004/12/09/72.html

http://www.presidenri.go.id/index.php/pidato/2010/05/24/1407.html 